plan was implemented". To Wells, the fossil record does not represent a continuum of ancestry, but a succession of creations by the Intelligent Designer, with each species carefully devised to nurture the next product of creation up to the final goal, humans.

But this argument is blasphemous, for its logical consequence is that the pinnacle of evolution is not Homo sapiens but our ectoparasite Pediculus humanus, the body louse. It also turns the Great Designer into a Great Deceiver, who, in the manner of Satan, put fossils in the rocks - and tails on embryos - to mislead biologists of the future.

Finally, Wells's main theme about the collusion of evolutionary biologists is simply wrong. Authors of some biology texts may occasionally be sloppy, or slow to incorporate new research, but they are not duplicitous. And, far from representing a conspira$\mathrm{cy}$, it is invariably evolutionists (including myself) who have noted problems with some classic icons of evolution. Wells has it backwards. It is creationists like him who are conspiring to purge evolution from American education. They hide their own differences about issues such as the fossil record and the age of the Earth, they pretend to be disinterested seekers after truth, they fail to do their own scientific research, and, like Wells, they avoid at all costs revealing their own theories about the history of life. Icons is exactly as even-handed and intellectually honest as one would expect from someone whose "prayers convinced me that I should devote my life to destroying Darwinism".

Jerry A. Coyne is in the Department of Ecology and Evolution, University of Chicago, Chicago, Illinois 60637, USA.

\section{A pillar of molecular biology}

\section{Ahead of the Curve: David Baltimore's Life in Science \\ by Shane Crotty \\ University of California Press: 2001. 372 pp.

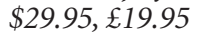

\section{Robert Bazell}

Many of his peers regard David Baltimore as the most important living figure in biology. His co-discovery in 1970 of the enzyme reverse transcriptase, which makes DNA from an RNA template, opened the way for, among other things, recombinant DNA, the modern understanding of cancer and most of what is known about HIV. All too often, a scientist's significant research ends with such a seminal Nobel prizewinning discovery. But not only has Baltimore's productivity continued unabated, his work has left "a lasting impact on virtually every realm of modern biology", according to one colleague. His dis- tinctive teaching style - a combination of frightening confrontation and passionate loyalty — has attracted and trained a large and elite corps of scientists who are now leaders in many areas.

And Baltimore's achievements extend beyond the research bench. He has served as president of two of the world's leading research universities: Rockefeller University, from which he was forced to resign, and the California Institute of Technology, where he now presides. He started and effectively ran the Whitehead Institute for Biomedical Research in Cambridge, Massachusetts, one of the most productive and innovative models for public-private research cooperation. $\mathrm{He}$ was involved in most of the prominent science-policy issues of the past 30 years, including the US government's declaration of a 'war' on cancer, the initial perceived dangers of genetic engineering, the response to the AIDS epidemic and, of course, the most famous and protracted allegation of scientific fraud ever - the Imanishi-Kari affair or, as it is often called, 'the Baltimore case', in which the researcher Thereza Imanishi-Kari was accused of falsifying data for a paper coauthored with Baltimore and published in Cell in 1986.

Because of that case, or perhaps because some people use it as an excuse for other agendas, Baltimore — to put it mildly faces detractors every bit as fervent as his supporters. James Watson, the co-discoverer of the structure of DNA and the embodiment of biology for the US public, actually campaigned to have Baltimore's Nobel prize rescinded and to have him expelled from the National Academy of Sciences. Others who were once considered Baltimore's close friends have behaved with only slightly less rancour.

Reading Shane Crotty's excellent book, we do not necessarily understand such horrid behaviour but we come to appreciate the context. Baltimore embodies molecular biology over the past 35 years, during which it evolved rapidly from an observational science to the Messiah of medicine, capable of delivering us from deadly degenerative diseases. It has become a magnet for so much money that even those marginally involved, not to mention the leaders, routinely make sizeable fortunes. This makes it fertile ground for monumental egos, and, much to the dismay of many of his contemporaries, Baltimore's powerful intellect and supreme, often abrasive self-confidence remained intact during the most trying times.

"Brilliant, eloquent and personable, Baltimore is a man whom even his closer friends refer to as arrogant and ruthless," Crotty, a postdoctoral fellow at the University of California, San Francisco, tells us early on. Unfortunately, we get little sense of the origins of Baltimore's personality. This is not a psychological biography. We learn that Balti-

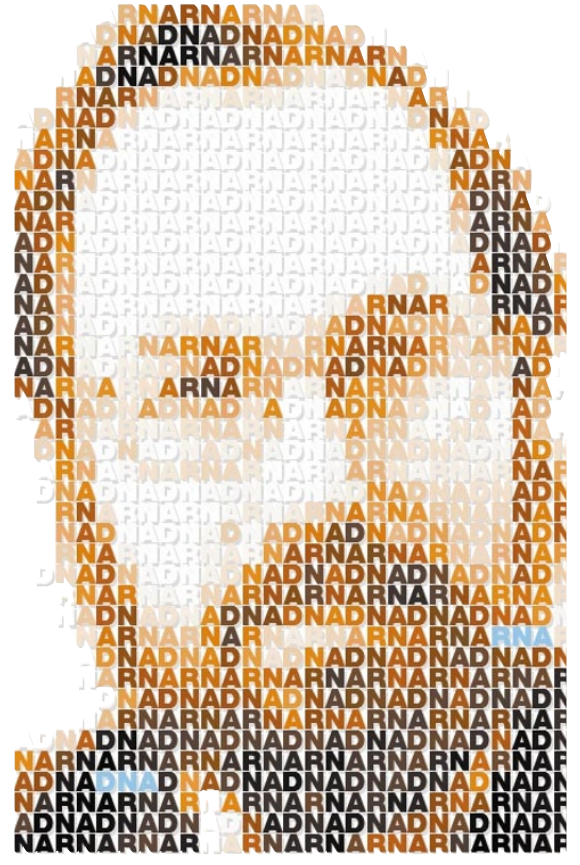

more adored his mother, but she, along with his father, is not even named in the book. The mother pushed David into biology by suggesting a high-school summer programme at the Jackson Laboratories in Bar Harbor, Maine. Throughout his training, Baltimore seldom attached himself to one mentor for long, possessing a keen appreciation of those who could teach him something and great disdain for those who could not. From his earliest days as a graduate student he was "a pain in the ass", one teacher recalls.

But the reader will find few personal anecdotes here. At one point Crotty quotes Baltimore about his time as a graduate student at Rockefeller University: "I'd go to the movies occasionally, had some love affairs and things, but - I did an awful lot of lab work. Loved it!" That's as juicy as it gets. Baltimore's first marriage and divorce, and his subsequent marriage to the prominent virologist Alice Huang, merit only a few lines. Because of this lack of personal detail, the reader gets little insight into Baltimore's emotions during the many vicissitudes of his career.

What the book does offer is fine science writing. From Baltimore's first experiments with mouse genetics during his high-school summer to recent efforts to accelerate the development of an effective AIDS vaccine, Crotty describes clearly the underpinnings of each stage of Baltimore's career in language accessible to the educated layman, but not condescending to the practising scientist. As a result, we understand not only the research, but also the policy issues and personality conflicts it generated. By the time we are told about Baltimore's discovery of reverse transcriptase, we can thoroughly grasp its importance and the reason for the excitement. When Crotty details the experiences in Stanford biologist Paul Berg's lab with the animal tumour virus SV40, it is easy 
to understand the initial terror Baltimore, Berg and others felt at the prospect of recombinant DNA experiments.

Crotty's retelling of the Imanishi-Kari affair also benefits from this clear detailing of the science. With the precisely focused lens of hindsight, and in enormous detail, Daniel Kelves' book The Baltimore Case: A Trial of Politics, Science, and Character (Norton, 1998) demonstrated the great injustice done to Imanishi-Kari and Baltimore. Crotty tells a more human story. The facts were not so clear at the time, and in the fog of misinformation Baltimore changed his own story more than once. This infuriated many who thought he went too far in attacking his critics, especially John Dingell, the bombastic Detroit congressman who chaired the congressional committee investigating the case. Although science itself was never on trial, as Baltimore and others alleged, Baltimore's ultimate exoneration was critically important for science because it restored one of its greatest practitioners to his deserved status. Crotty's book brilliantly illuminates this pillar of molecular biology, and should be read by anyone, whether scientist or not, who cares about the modern research enterprise and the politics that drive it.

Robert Bazell is at NBC-TV, 30 Rockefeller Plaza, New York, New York 10112, USA.

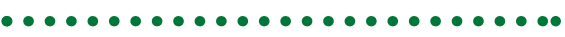

\section{What every}

\section{woman knows}

\section{Athena Unbound: The \\ Advancement of Women in \\ Science and Technology \\ by Henry Etzkowitz, Carol Kemelgor \\ \& Brian Uzzi \\ Cambridge University Press: 2000. 282 pp. \\ $\mathfrak{E} 12.95, \$ 19.95$}

The Gender and Science Reader

edited by Muriel Lederman

\& Ingrid Bartsch

Routledge: 2001. 505 pp. $£ 55, \$ 90$ (hbk),

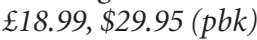

\section{Sylvie Coyaud}

In spite of its subtitle, Athena Unbound has little 'advancement' to report in the lives of the American women scientists interviewed by the authors. Only the most determined were able to overcome early stereotypes of what girls should be like at home, at school or in society, as well as later prejudices. Girls tend to leave college with higher exam results than boys and with reasonable selfassurance. Then, from university onwards, they are made to feel out of place in labs, pubs and the other meeting places where gossip and information are swapped and where men receive their informal training in career-long networking.
The book contains few in-depth interviews, but the scientists selected have perceptive things to say about their own and other women's failures. Their testimony often contradicts prevailing assumptions and policies. For instance, they say that the impact of role models - older women in top jobs who function as beacons for young students has been overrated. The poor 'models' have to struggle so hard to stay on top and are so obviously exhausted that only masochists would emulate them. The 'critical mass' theory, according to which a sufficiently large number of women researchers in a field would lead to a change in the power structure, doesn't stand the test either. This naive idea goes against experience: in some areas of the life sciences women are in the majority, but are kept firmly on the lower rungs, where a large and not too skilled labour force is needed. The same thing happened in medicine in European countries, and in road building in the Soviet Union.

The authors, two sociologists and a psychotherapist, want to dispel clichés about the inability of women to survive in a harsh environment. Not that they need to sell this argument - the large numbers of women raising a family as single mothers on a part-time salary are proof enough of their resilience. And although the authors' quantitative analysis method is respectable, job and pay statistics already tell the whole story. The book, though slim, feels over-long, because its unstartling conclusions are hammered home by the American habit of summarizing a chapter's contents at the end of that same chapter, as if readers were memory-impaired.

The Gender and Science Reader covers the same ground from the point of view of the feminist critique of science. It is a collection of essays and book extracts from the best English-language authors, from well-known feminist writers such as Donna Haraway, Evelyn Fox Keller, Hilary Rose and Carolyn Merchant, to newer entrants such as biologists Christine Wennerås and Agnes Wold, who discovered the 2.6 factor (they showed that women had to publish 2.6 times more than men in order to obtain the same quality scores for postdoctoral fellowship applications submitted to the Swedish Medical Council; see Nature 386, 341-343; 1997).

The book starts with a survey of (mainly US) data on the low status of women scientists. This is followed by a critique of scientific methods and values and of the underlying ideas about 'nature'. The editors nicely balance the different schools of feminist theory. For example, Sarah Harding's essay "Is science multicultural?" is followed by Helen Longino's "Subject, power, and knowledge", a review of feminist epistemological strategies. Longino herself favours "the inclusion of cognitive diversity", whether gendered or cultural, within the scientific community "as a resource for criticism of the received wisdom", but doesn't believe "that every alternative view is equally deserving of attention".

Longino is in turn followed by John Lukacs, a "historian of twentieth-century European culture who brings a strongly religious perspective to his discussion of ... quantum mechanics". Lukacs treads less cautiously than the other two men who contribute to this anthology. One suspects his essay on "Heisenberg's recognitions", which discusses the "historicity of reality as something which is prior to its mathematicability" in relation to human nature, has been included to underscore the rationality of feminist authors. Comic relief is provided by chapters on "Gender practice" and "Science and identity", which tell how past research in the life sciences proceeded apparently unaware that human organisms, unlike bacteria, come in two versions, or

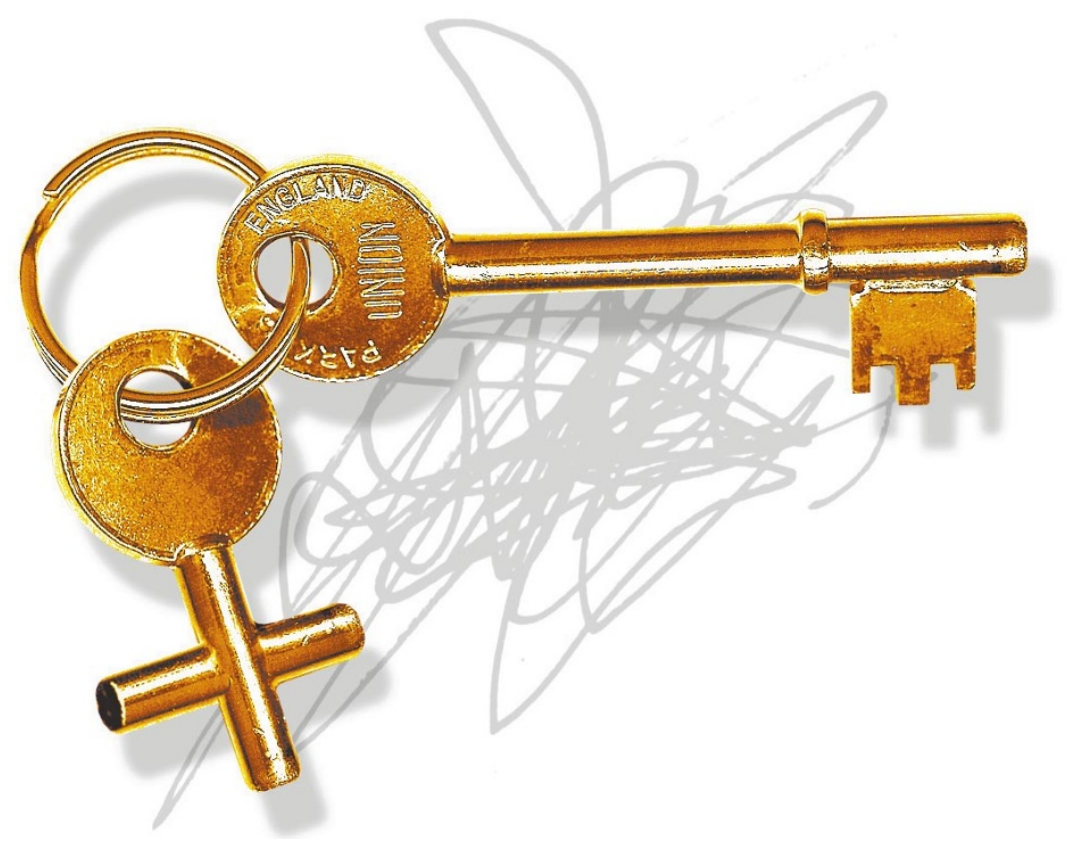

^ ๔ 2001 Macmillan Magazines Ltd 